Ks. Łukasz Florczyk

Verbum Vitae 28 (2015) 27-58

\title{
KAMIEŃ - ŚWIADEK PRZYMIERZA W SYCHEM (JOZ 24,1-28)
}

\section{Stone - a Witness of the Covenant in Shechem (Joshua 24:1-28)}

\begin{abstract}
Stones have always been used in the everyday life of people living in Canaan. They have also served as witnesses of important events in the history of the Chosen People, carrying within themselves a certain message for people, both for those times and to future generations. An example of one such witness is the great stone which Joshua had set up under an oak in Shechem on the occasion of the renewal of the covenant between God and the Israelites. The stone was to remind them about the miraculous interventions of Yahweh in the story of the Chosen People, about solemn declarations which they had vowed to God (mostly the resignation of the worship of foreign gods and abiding by the Law, which was to guarantee God's blessing), and about the covenant made, or renewed, on that spot.
\end{abstract}

Keywords: Shechem, Joshua, covenant, stone, witness, testimony

Streszczenie: Kamienie były często wykorzystywane w codziennym życiu mieszkańców Kanaanu. Pełniły one także funkcję świadków ważnych wydarzeń w historii narodu wybranego oraz niosły ze sobą konkretne przesłanie dla ówczesnych ludzi i przyszłych pokoleń. Takim świadkiem był chociażby wielki kamień, który Jozue umieścił pod terebintem w Sychem, w związku z od- 
nowieniem przymierza między Bogiem a Izraelitami. Kamień ten miał przypominać Izraelitom o cudownych interwencjach Jahwe w dziejach narodu wybranego, o pięknych deklaracjach, do których zobowiązali się Izraelici wobec Boga (przede wszystkim chodziło o odrzucenie kultu obcych bóstw i przestrzeganie przepisów Prawa, co miało zagwarantować Boże błogosławieństwo) oraz o zawartym przymierzu.

Słowa klucze: Sychem, Jozue, przymierze, kamień, świadek, świadectwo

Pamięć jest bardzo ważna w życiu każdego człowieka. To dzięki niej można przedłużać w teraźniejszości skuteczność minionych zdarzeń i je uobecniać. Celem wspomnień jest powrócenie do ważnych wydarzeń i przywrócenie na nowo dawnych stosunków ${ }^{1}$. Psalmista głosi przecież: „Błogosław duszo moja Pana i nie zapominaj o wszystkich Jego dobrodziejstwach" (Ps 103,2)².

Warto w tym miejscu zwrócić uwagę chociażby na żydowską Paschę. To święto było obchodzone na pamiątkę wyzwolenia Izraela z niewoli egipskiej. Odnosiło się ono nie tylko do przeszłości, ale też do przyszłości, ponieważ z obchodem Paschy było związane oczekiwanie na przyjście Mesjasza. Każda uczta paschalna (z tradycyjnymi potrawami) miała nie tylko przypominać uczestnikom o pierwszej Passze, ale też ją uobecniać.

Anamneza pełniła i nadal pełni w Izraelu bardzo ważną funkcję antropologiczną, cieszyła się ogromnym uznaniem, kształtowała tożsamość narodową i religijną za pomocą słowa oraz odpowiednich symbolicznych rytów ${ }^{3}$. Wszelkie pamiątki i świadectwa (np. słowa, ryty, obchodzone święta, zachowane dokumenty i przedmioty,

${ }^{1}$ Corbon, „Pamięć”, 639.

${ }^{2}$ Cytaty biblijne zostały zaczerpnięte z: Pismo Święte Starego $i$ Nowego Testamentu. W przekładzie z języków oryginalnych opracował zespół Biblistów Polskich z inicjatywy Benedyktynów Tynieckich (Poznań ${ }^{5}$ 2002).

${ }^{3}$ Zob. Nadolski, „Eucharystia”, 406. 
ustawiane kamienie) miały przypominać ludziom o określonych wydarzeniach i działaniach ${ }^{4}$.

\section{Motyw kamienia na kartach Starego Testamentu}

Ludy pierwotne otaczały kamienie szczególną czcią. Było to związane $\mathrm{z}$ ich trwałością, kształtem czy też faktem, że dzięki nim można było rozniecić ogień. Kamienie były symbolem życia i płodności. Wykorzystywano je także do tego, by przedłużać pamięć o ludziach zmarłych, których podobizny i imiona utrwalano właśnie w kamienius.

Kult świętych kamieni był zakazany w Izraelu ${ }^{6}$. Bóg stanowczo zażądał od swego ludu, by ten nie brał wzoru z ościennych pogańskich plemion i nie służył „drewnu i kamieniowi” (Ez 20,32) oraz dodał: „Na moje życie! [...] Oto Ja będę panował nad wami mocną ręką i wyciągniętym ramieniem, i ze strasznym gniewem" (Ez 20,33). $\mathrm{Z}$ drugiej jednak strony Kanaan był bogaty w kamienie, dlatego były one tak ważne w codziennym życiu jego mieszkańców ${ }^{7}$ i stały się częstym motywem pojawiającym się na kartach Pisma Świętego.

Kamienie były wykorzystywane m.in.: do siedzenia (Wj 17,12); do rozniecania ognia (2 Mch 10,3); przy ważeniu (Prz 16,11); jako stosowny ciężar pociągający za sobą w dół przymocowany doń przedmiot, obiekt $(\mathrm{Jr} 51,63)$;

${ }^{4}$ Achtemeier, „Pamiątki”, 894.

${ }^{5}$ Zob. Lurker, „Kamień”, 82.

${ }^{6}$ Świadczą o tym m.in. następujące teksty Pisma Świętego: „Nie będziecie sobie czynili bożków, nie będziecie sobie stawiali posągów ani stel. Nie będziecie umieszczać w waszym kraju kamieni rzeźbionych, aby im oddawać pokłon, bo Ja jestem Pan, Bóg wasz” (Kpł 26,1); „Nie postawisz steli, której nienawidzi Pan, Bóg twój” (Pwt 16,22); „Gładkie kamienie potoku są twoim działem, one to, one - twoją częścią wylosowaną. Im też w ofierze wylewałaś płyny, ofiarowałaś obiaty. Czyż mam być z nich zadowolony?" (Iz 57,6).

${ }^{7}$ Deden, „Stein”, 1636. 
jako idealna kryjówka (Syr 29,10); jako zamknięcie studni, naczynia lub grobu $(\operatorname{Rdz} 29,2)$ czy też do zabarykadowania wejścia (1 Mch 5,47). Za pomocą ostrych kamieni dokonywano obrzezania napletka (Wj 4,25; Joz 5,2-3). Kamienie stosowano do niszczenia, np. pól (2 Krl 3,19.25; Iz 5,2) lub miast (1 Mch 6,51). W Piśmie Świętym spotyka się także motyw kamieni młyńskich (Pwt 24,6) czy kamiennych stągwi przeznaczonych do żydowskich oczyszczeń (J 2,6). Zdarzało się, że kamieniami rzucano w drugiego człowieka (tak np. postąpił Szimei, syn Gery, względem Dawida oraz jego służby - $2 \mathrm{Sm} 16,5-14)$ lub w zwierzę (Syr 22,20). W Wj 21,18-19 odnaleźć można przepis prawny odnośnie do człowieka, który podczas kłótni rzucił kamieniem w drugą osobę. Winny takiego zajścia „będzie wolny, wynagrodzi przerwę w pracy [zranionemu przez siebie człowiekowi] i dołoży starań, żeby go wyleczyć" (Wj 21,19). Znano również karę śmierci przez ukamienowanie (Joz 7,16-26).

Kamienie podkreślały ważne etapy życia Jakuba. Warto $\mathrm{w}$ tym miejscu przywołać chociażby epizod z życia tego patriarchy, który został opisany w Rdz 28,10-22. Jakub podczas wędrówki z Beer-Szeby do Charanu zatrzymał się w pewnym miejscu na nocleg. Swą głowę położył na kamieniu i zasnął. Podczas snu ujrzał drabinę, która swym wierzchołkiem sięgała nieba, oraz aniołów zmierzających ku górze i schodzących. Na szczycie drabiny stał Pan, który przemówił do Jakuba tymi słowami: „Ja jestem Pan, Bóg Abrahama i Bóg Izaaka. Ziemię, na której leżysz, oddaję tobie i twemu potomstwu. A potomstwo twe będzie tak liczne jak proch ziemi, ty zaś rozprzestrzenisz się [...], wszystkie plemiona ziemi otrzymają błogosławieństwo przez ciebie i przez twych potomków. Ja jestem z tobą i będę cię strzegł, gdziekolwiek się udasz, a potem sprowadzę cię do tego kraju. Bo nie opuszczę cię, dopóki nie spełnię tego, co ci obiecuję" (Rdz 28,13-15). Gdy Jakub wstał rano, wziął kamień, który nocą miał pod swoją gło-

${ }^{8}$ Niektóre motywy zostały zaczerpnięte z: Deden, ,Stein”, 16361637. 
wą, ustawił go jako stelę, rozlał na nim oliwę, a miejscu temu dał nazwę Betel.

Skała na pustyni, z której wytrysnęła woda do picia dla narodu wybranego ( $\mathrm{Wj} 17,1-7)$, doczekała się wielu interpretacji. Utożsamiano ją z Jahwe, który wiernie towarzyszył swojemu ludowi w wędrówce przez pustynię; była symbolem Bożego błogosławieństwa (zob. Ez 47,1-12; Za 14,8 i Ap 22,1) oraz wyrazem miłosiernej mocy Jahwe, który z twardego, suchego i pozbawionego życia kamienia wydobył życiodajną wodę. Nie dziwi więc fakt, że motyw ten był często przywoływany przez biblijnych autorów (np. Ps 78,15; 105,41; Mdr 11,4)9.

$\mathrm{Z}$ nieciosanych kamieni budowano ołtarze ( $\mathrm{Wj} 20,25$; $\mathrm{Sdz}$ 6,11-24). Kamień miał też ścisły związek z Dekalogiem, ponieważ Dziesięcioro Przykazań zostało wypisanych właśnie na kamiennych tablicach (Wj 24,12-18). Z czasem „kamienne serce" stało się synonimem zatwardziałości Izraelitów, dlatego też Bóg zapowiedział zawarcie Nowego Przymierza, którego prawo zostanie wyryte już nie na kamieniu, ale na ludzkim sercu (zob. Hi 41,16; Jr 31,31-34; Ez 11,19; 36,26).

Kamienie służyły także do tego, by upamiętnić zawarte traktaty i przymierza (Rdz 31,42-54; Joz 4,7.20-24; 24,26-27) oraz zmarłe osoby (Joz 8,29; 2 Sm 18,17). Symbolizowały one również pokolenia izraelskie. Przykładem tego może być epizod z życia Mojżesza, który zbudował ołtarz dla Pana i ustawił dwanaście stel - „stosownie do liczby dwunastu pokoleń Izraela" (Wj 24,4). W Wj 28,6-14 odnaleźć można instrukcję wykonania efodu. Jego zasadniczym elementem były dwa kamienie onyksowe, na których wyryto imiona synów Izraela - po sześć imion na każdym kamieniu. Zachowano przy tym porządek chronologiczny odnośnie do czasu urodzenia się poszczególnych synów Jakuba. Z kolei dwanaście drogocennych kamieni (rubin, topaz, szmaragd, granat, szafir, beryl, opal, agat, ametyst,

${ }^{9}$ Lamarche, „Kamień”, 361. 
chryzolit, onyks oraz jaspis) ${ }^{10}$ zdobiło pektorał, którego opis umieszczony został w $\mathrm{Wj}$ 28,15-30. Kamienie te były ułożone w czterech rzędach - po trzy kamienie w każdym. Miały one również przywoływać na myśl dwanaście pokoleń Izraela.

Na szczególną uwagę zasługuje jeszcze kamień fundamentowy. To właśnie od niego rozpoczynano wznoszenie budowli. Najczęściej tym kamieniem fundamentowym był kamień węgielny. Było na nim wyryte imię osoby, która wznosiła budowlę, a gdy chodziło o obiekty sakralne, to zamieszczano na nim imię stosownego bóstwa. Umieszczanie kamieni fundamentowych było ważną funkcją królów oraz kapłanów ${ }^{11}$. Istniało przekonanie, że skoro twórcą wszechświata jest Bóg, to ziemia musi być osadzona na solidnym i trwałym fundamencie (zob. 1 Sm 2,8; Hi 38,4-7). O takie podłoże zabiegał również król Salomon podczas budowy Świątyni Jerozolimskiej: „Król polecił im [wykonawcom prac] wyłamywać kamienie wielkie, wyborowe i ciosane na założenie fundamentów budowli. Murarze więc Salomona i murarze Hirama wraz z Giblitami ciosali oraz przygotowywali drewno i kamienie na budowę świątyni" (1 Krl 5,31-32).

Bóg położył także kamień na Syjonie - „kamień dobrany, węgielny, cenny, do fundamentów założony" (Iz 28,16). Ten, kogo będzie cechowała wiara i wierność, nie potknie się o ten kamień (zob. Iz 28,16; Ps 91,12). I przeciwnie - Bóg będzie skałą potknięcia dla grzesznika: „On [Pan Zastępów] będzie kamieniem obrazy i skałą potknięcia się dla obu domów Izraela; pułapką i sidłem dla mieszkańców Jeruzalem. Wielu z nich się potknie, upadnie i rozbije, będą usidleni i w niewolę wzięci" (Iz 8,14-15). Wszystko zatem zależy od ludzkiej odpowiedzi na Boże wezwanie do świętości.

Do kamienia węgielnego nawiązuje również Ps 118: „Kamień odrzucony przez budujących stał się kamieniem

${ }^{10} \mathrm{Z}$ drogocennych kamieni będzie też zbudowana nowa Jerozolima (zob. Tb 13,17-18; Iz 54,11-12; Ap 21,9-21).

${ }^{11}$ Zob. Lurker, „Kamień węgielny”, 83. 
węgielnym" (Ps 118,22). O kim myślał autor natchniony, gdy zapisywał te słowa? Aramejska parafraza tego tekstu w Targumie przywołuje na myśl Dawida: „Młodzieniec, którego odrzucili budowniczy, zaliczał się do synów Jessego i był godny stać się królem i panować" ${ }^{2}$. Jeszcze inne interpretacje odnoszą ten tekst do Izraela oraz do Mesjasza.

Kamienie odgrywały zatem ważną rolę w codziennym życiu mieszkańców Kanaanu i dlatego stały się one częstym motywem spotykanym na kartach Pisma Swiętego.

\section{Kamień-Świadectwo w Księdze Jozuego}

Kamień, ze względu na swoją twardość, nieustępliwość i odporność na bodźce zewnętrzne, stał się symbolem martwoty, surowości, braku życia oraz jakichkolwiek uczuć. Jednak z drugiej strony można odnaleźć na kartach Pisma Świętego fragmenty, w których kamienie są wprost nazwane świadkami konkretnych wydarzeń. Te kamienie stają się niejako żywymi bytami. Swiadek bowiem jest obserwatorem jakiegoś zajścia, jest w stanie o nim opowiedzieć, przekazuje konkretne przesłanie oraz potrafi w późniejszym czasie przypomnieć innym osobom o zaistniałej niegdyś sytuacji. Często jest i tak, że świadek nie musi niczego mówić, gdyż samo spojrzenie na niego przywołuje w pamięci obrazy z przeszłości. Taką właśnie funkcję pełnią kamienie-świadectwa. Warto także nadmienić, iż archeolodzy odkryli kilka kamiennych kręgów. Na niektórych wyryte były nawet oczy lub ręce. Zapewne były to kamienie, które odgrywały rolę świadków przymierza, traktatu lub były elementem religijnych obrzędów ${ }^{13}$.

${ }^{12}$ Zob. Ryken - Wilhoit - Longman, „Kamień węgielny”, 295.

${ }^{13}$ Zob. Ryken - Wilhoit - Longman, „Kamień węgielny”, 294. W starożytności istniał zwyczaj wznoszenia kamiennych filarów jako pomników publicznych transakcji, zob. Jamieson - Fausset - Brown, Commentary, I, 157. W wielu kulturach ustawiano kamienie, by w ten sposób upamiętnić jakieś ważne wydarzenie, np. rozegraną bitwę, zob. Spence-Jones, Joshua, 62. 
W Księdze Jozuego można napotkać kilka motywów kamieni. Wszystkie one były świadkami ważnych wydarzeń w dziejach narodu wybranego. Po raz pierwszy motyw kamienia w Księdze Jozuego występuje w związku z przejściem Izraelitów przez Jordan (Joz 3-5,1; 7,7). Wydarzenie to miało miejsce wiosną. Kananejczycy byli przekonani, że z powodu wezbranych wód Jordanu nie muszą obawiać się Izraelitów, którzy rozbili obóz po drugiej stronie rzeki ${ }^{14}$. Izraelitom jednak udało się przejść przez Jordan, ale konieczna była przy tym Boża interwencja. $\mathrm{Na}$ czele ludu zmierzającego w stronę rzeki szli kapłani niosący Arkę Przymierza. W momencie, gdy nogi kapłanów zanurzyły się w Jordanie, ,zatrzymały się wody płynące z góry i utworzyły jakby wał na znacznej przestrzeni od miasta Adam leżącego w pobliżu Sartan, podczas gdy wody spływające do morza Araby, czyli Morza Słonego, oddzieliły się zupełnie [...]" (Joz 3,16). Wówczas wszyscy Izraelici mogli przejść na drugi brzeg po suchej ziemi. Gdy już cały naród skończył przeprawę przez Jordan, Bóg zwrócił się do Jozuego z poleceniem, aby dwunastu mężczyzn (po jednym z każdego pokolenia) zabrało ze środka Jordanu dwanaście kamieni i przeniosło je do obozu. Tak też się stało. Taką samą liczbę kamieni umieścił również Jozue na środku Jordanu. Gdy wszystko zostało wykonane zgodnie z Bożym nakazem, kapłani niosący Arkę Przymierza wyszli jako ostatni z rzeki, a wówczas wody wróciły na swoje miejsce. Izraelici - po przejściu Jordanu - rozbili obóz w Gilgal. Tam też ustawiono dwanaście kamieni, które mężczyźni zabrali z koryta rzeki.

Kamienie te były świadkami Bożej interwencji oraz miały przypominać następnym pokoleniom o konieczności odznaczania się Bożą bojaźnią, o potężnej mocy Pana, o tym, że jak niegdyś Bóg cudownie przeprowadził swój lud przez Morze Sitowia [Czerwone], tak też przeprawił Izraelitów przez Jordan. Te kamienie (אֶֶ, - 'eben [1. poj.];

${ }^{14}$ Synowiec, Izrael opowiada swoje dzieje, 73. 


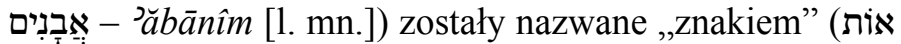

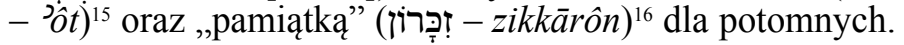

Wkrótce Izraelici zdobyli Jerycho (Joz 6,1-27). Nie byłoby to możliwe, gdyby Bóg nie wspierał swego ludu. Pan powiedział bowiem do Jozuego: „Spójrz, Ja daję w twoje ręce Jerycho wraz z jego królem i dzielnymi wojownikami" (Joz 6,2). Zdobycie Jerycha przebiegło w następujący sposób: codziennie (przez sześć dni) Izraelici okrążali miasto jeden raz i wracali do swojego obozu. $\mathrm{Na}$ czele procesji szli uzbrojeni wojownicy, których zadaniem było wzbudzać strach oraz pilnować Arki Przymierza. Za nimi kroczyli kapłani grający na trąbach z rogów baranich. Następnie niesiono Arkę Przymierza, za którą podążała tylna straż oraz lud. Siódmego dnia Izraelici okrążyli Jerycho aż siedem razy. Przy siódmym okrążeniu, gdy kapłani zagrali na trąbach, Jozue rozkazał ludowi, by ten wzniósł okrzyk wojenny. Na ten dźwięk runęły mury Jerycha. Izraelici wtargnęli do miasta i pozabijali jego mieszkańców oraz zwierzęta. Ocalała tylko Rachab i jej rodzina, gdyż w przeszłości ukryła ona izraelskich zwiadowców, którzy przybyli do Jerycha, by wybadać teren (zob. Joz 2). Izra-

${ }^{15}$ Zob. Joz 4,6. Stary Testament zna dwa terminy na oznaczenie znaku - 'ôt oraz môpēt. Pierwszy z nich określa cuda oraz symboliczne czyny, a drugi może oznaczać konkretną osobę. Obydwa pojęcia w jakimś stopniu się uzupełniają. To wzajemne współprzenikanie można dostrzec w samoobjawieniu się Pana (Wj 3,14-15). Objawione wówczas Boże imię JESTEM, KTÓRY JESTEM oznacza jego osobowy byt (znak $\mathrm{w}$ rozumieniu môpét) oraz mówi o cudownych czynach nakierowanych na ludzi i ich zbawienie (znak w rozumieniu 'ôt). Więcej informacji na temat rozumienia pojęcia znaku na kartach Pisma Świętego odnaleźć można w: Rabiej, „Soteriologiczne znaczenie Chrystusowego EGO EIMT', 15-27.

${ }^{16}$ Zob. Joz 4,7. Słowo to oznacza pamięć, przypominanie czegoś, co miało miejsce w przeszłości, zob. Edel, Hebräisch-Deutsche Präparation zu Josua, 15 . Chodzi o rozpamiętywanie tego, co wydarzyło się dawno, o przypominanie ludziom wielkich dzieł Boga oraz o powoływanie się wobec Niego na Jego dobrodziejstwa. Wyraz ten oznacza także dziękczynienie, zob. Świderkówna, „Od Paschy pierwszego Przymierza do Eucharystii”, 131. To wspominanie służy uteraźniejszaniu tego, co wydarzyło się w przeszłości, zob. Corbon, „Pamięćc, 641. 
elici spalili Jerycho, a wszelkie złoto, srebro oraz naczynia z brązu i żelaza przekazali do skarbca Pańskiego. Na koniec Jozue rzucił klątwę na miasto oraz na tych, którzy podjęliby się jego odbudowy ${ }^{17}$. Mury Jerycha były zatem świadkami opisanych wydarzeń, a gruzy tego miasta miały przypominać o tym, że tylko bliskość i przychylność Jahwe jest gwarancją zwycięstwa.

Klątwę rzuconą na Jerycho zlekceważył Akan - syn Karmiego (Joz 7,1.6-26; 22,20). Po zdobyciu Jerycha przywłaszczył sobie kosztowny płaszcz, srebro i pręt złota. Wszystkie te dobra ukrył, a następnie zakopał w swoim namiocie. Ten haniebny czyn stał się powodem klęski pod Aj (zob. Joz 7,2-5). Bóg zażądał wówczas od Jozuego ukarania winnego i oświadczył: „Nie będę nadal z wami, jeśli nie wytępicie wśród siebie dotkniętych klątwą" (Joz 7,12). Akan został odkryty przez losowanie (zob. też: $1 \mathrm{Sm} 10,19-24 ; 14,40-43$; Jon 1,7; Dz 1,26). Mimo iż przyznał się do zarzucanych mu czynów, został ukamienowany przez lud. Wzniesiono nad nim także wielki stos kamieni, a miejsce to nazwano Akor.

Kamienie, których użyto do zabicia Akana, były świadkami tragicznego losu tego człowieka. Natomiast wielki stos kamieni nad jego zwłokami miał przypominać, że sprzeciwianie się Bożej woli prowadzi człowieka

${ }^{17}$ Hebrajskie słowo חִ (hērem) można tłumaczyć jako: „klątwa”, „to, co obłożone klątwą”, „przeznaczone na zagładę”, ,poświęcone na zniszczenie”, ,poświęcone Bogu”. Chodziło głównie o rzeczy należące do nieprzyjaciół, które niszczono po działaniu zbrojnym, a ludzi i zwierzęta - zabijano. Zagarnięcie czegoś, co zostało obłożone klątwą, karane było śmiercią - tak jak po zetknięciu się z tabu. Pierwotnie hêrem stanowił rodzaj ofiary składanej Bogu - Panu wojen - z życia wrogów. Klątwa służyła odseparowaniu się od tego wszystkiego, co mogło zagrozić religijnemu życiu Izraela. Była środkiem przeciwko idolatrii. Jej celem było m.in.: zapobiegnięcie mieszanym małżeństwom, oczyszczenie zdobytej ziemi, co często dokonywało się za pomocą masowej rzezi, miecza i ognia oraz ustalenie granicy pomiędzy ludami Kanaanu, a narodem wybranym, zob. więcej w: Michalak, „Rytuał klątwy”, 9-23. 
do nieszczęścia oraz że wina jednostki może powodować negatywne konsekwencje dla całego narodu ${ }^{18}$.

Dopiero po ukamienowaniu Akana Izraelitom udało się zdobyć Aj (Joz 8). Mogli oni na nowo doświadczyć tego, że wspiera ich Pan. Bóg powiedział bowiem Jozuemu: „Patrz: oto wydaję w twoje ręce króla Aj, jego lud, miasto i kraj" (Joz 8,1). Miasto zostało zdobyte podstępem. Część izraelskich wojowników ukryła się i przygotowała zasadzkę po zachodniej stronie Aj. Druga część - na czele z Jozuem - ruszyła na miasto od strony północnej. Gdy ujrzał ich król Aj, zwołał wszystkich ludzi ze swego miasta i wraz z nimi wyruszył do boju. Jozue i jego wojownicy zmienili wtedy kierunek i zaczęli przed nim uciekać. Była to przemyślana taktyka, gdyż w ten sposób ścigający Izraelitów król Aj i jego podwładni oddalili się od swego miasta. W tym czasie druga ekipa Jozuego, która stacjonowała w ukryciu po zachodniej stronie Aj, podbiegła do opustoszałego miasta, zajęła je i podpaliła. Gdy Jozue w oddali ujrzał dym, przestał uciekać ze swymi wojownikami, zawrócił i zaatakował króla Aj oraz jego lud. W tym samym czasie Izraelici, którzy zdobyli miasto i je podpalili, ruszyli na pomoc Jozuemu. Król Aj i jego wojownicy znaleźli się w potrzasku. Izraelici pozabijali tego dnia wszystkich mieszkańców Aj. Nikomu nie udało się uciec. Miasto zostało obłożone klątwą i pozostało $\mathrm{z}$ niego tylko rumowisko. Izraelici (nie tak, jak w przypadku Jerycha) zabrali z Aj bydło oraz łupy i podzielili je między siebie. Król Aj został powieszony. Po ściągnięciu jego zwłok wzniesiono nad ciałem wielki stos kamieni (podobnie, jak w przypadku Akana). Następnie Jozue zbudował ołtarz na górze Ebal i złożył na nim ofiary uwielbienia oraz biesiadne. Potem sporządził na kamieniach odpis Prawa i odczytał je wobec całego zgromadzenia Izraela.

Gruzy Aj, stos kamieni nad zamordowanym królem tego miasta, kamienny ołtarz oraz odpis Prawa na kamieniach były świadkami kolejnych wielkich i chwalebnych wydarzeń $\mathrm{w}$ historii narodu wybranego po przejściu Jor-

${ }^{18}$ Zob. Bosak, „Akan”, I, 248. 
danu i wkroczeniu do Kanaanu. Miały one także przypominać, iż Jahwe jest Panem dziejów i to od Niego zależy ich bieg.

Kolejny raz motyw kamieni występuje w Joz 10,1-27. Pięciu królów amoryckich (król Jerozolimy, Hebronu, Jarmutu, Lakisz i Eglonu) natarło na miasto Gibeon. Jego mieszkańcy, którzy wcześniej przy użyciu podstępu zawarli porozumienie z Izraelitami (zob. Joz 9), posłali po Jozuego i poprosili go o militarne wsparcie. Wojska izraelskie zadały tak wiele strat koalicji królów amoryckich, że ci musieli przed nimi uciekać. W tej walce uczestniczył także sam Bóg, który zrzucał na uciekinierów ogromne kamienie z nieba. Kananejczycy znaleźli się bowiem w zasięgu potężnej burzy, którą zesłał Pan i w wyniku której wielu $\mathrm{z}$ nich zginęło od potężnego gradu ${ }^{19}$.

Pięciu królom amoryckim udało się jednak uciec i znaleźć schronienie w jaskini Makkedy. Gdy powiadomiono o tym Jozuego, ten nakazał, by zamknięto otwór wielkimi kamieniami i postawiono straż. Po jakimś czasie Jozue zarządził wyprowadzenie więźniów z jaskini. Następnie polecił swoim dowódcom, aby postawili swe nogi na ich karkach. Ta czynność miała podkreślić zwycięstwo Izraelitów oraz hańbę i upokorzenie królów amoryckich. Zostali oni zabici oraz powieszeni na pięciu drzewach. $\mathrm{O}$ zachodzie słońca zdjęto ich ciała i wrzucono do jaskini, w której wcześniej się ukrywali. Wejście natomiast zasypano wielkimi kamieniami.

Kamienie zrzucane przez Boga z nieba oraz te, którymi zamknięto wejście do jaskini ze zwłokami pięciu królów amoryckich, były świadkami zwycięstwa Jozuego i jego armii oraz klęski ich nieprzyjaciół. Miały one również przypominać o tym, że sam Bóg walczył po stronie Izraelitów, a nawet walczył za nich (zob. Joz 10,14.42; $13,6 ; 23,3.10)$.

Motyw kamienia pojawia się także w Joz 22. Ziemia Kanaan została już rozdysponowana pomiędzy poszczególne pokolenia Izraela. Jedynie Rubenici, Gadyci oraz

${ }^{19}$ Schildenberger, Literarische Arten, 29-31. 
połowa pokolenia Manassesa otrzymali swój przydział po drugiej stronie Jordanu. Do tej pory pomagali oni pozostałym pokoleniom w przejmowaniu Kanaanu. Teraz ich misja się zakończyła i ze zdobytymi łupami oraz błogosławieństwem Jozuego mogli powrócić do swoich posiadłości za Jordanem. Jednak w drodze powrotnej, będąc już nad Jordanem (ale nadal w kraju Kanaan), Rubenici, Gadyci i połowa pokolenia Manassesa zbudowali okazały ołtarz. Ta sytuacja zaniepokoiła pozostałych Izraelitów, którzy wysłali do nich Pinchasa oraz dziesięciu książąt, aby ci wyjaśnili zaistniałą sytuację niewierności i buntu wobec Boga Izraela. Zwrócili się oni do pokoleń, które zbudowały ołtarz nad Jordanem m.in. takimi słowami: „Jeśli ziemia waszego dziedzictwa jest nieczysta, przejdźcie do kraju, który jest dziedzictwem Pana, gdzie wznosi się przybytek Pana i obierzcie mieszkanie pomiędzy nami. Nie buntujcie się jednak przeciw Panu i nie buntujcie się przeciwko nam, budując sobie ołtarz poza ołtarzem Pana, Boga naszego [...]" (Joz 22,19).

Rubenici, Gadyci i połowa pokolenia Manassesa zaczęli się usprawiedliwiać, że zbudowany przez nich ołtarz nie miał być wyrazem buntu lub niewierności. Nie mieli bowiem zamiaru składać na nim ofiar. Ołtarz ten miał

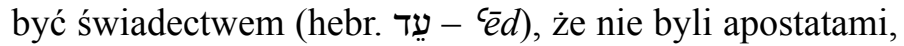
lecz chcieli być zawsze wierni Panu. Mieli bowiem jasną wizję przyszłości i pragnęli zachować narodową zgodę. Cechowała ich troska o wychowanie przyszłych pokoleń - właściwa Księdze Powtórzonego Prawa (Pwt 6,20-25; zob. Joz 4,6-7.21-24). Ołtarz ten miał być świadectwem, że plemiona zajordańskie pragnęły, by ich dzieci pozostały wierne Panu i były ściśle zjednoczone z pozostałymi pokoleniami (jak bracia i siostry) - pomimo dzielącej ich odległości ${ }^{20}$. Słowa te zostały przyjęte przez Pinchasa oraz jego towarzyszy. Zaistniały konflikt został zażegnany.

Opisane powyżej motywy kamienne (dwanaście pamiątkowych kamieni wyciągniętych z dna Jordanu; gruzy Jerycha; stos kamieni wzniesiony nad zwłokami Akana;

${ }^{20}$ Sanchez Cetina, „Księga Jozuego”, 451. 
gruzy Aj; stos kamieni nad ciałem króla Aj; ołtarz na górze Ebal; odpis Prawa na kamieniach; kamienie zrzucane przez Boga na wojsko królów amoryckich; kamienie zamykające wejście do jaskini, do której wrzucono pięciu królów pokonanych przez Jozuego i jego ludzi oraz ołtarz plemion zajordańskich) były świadkami ważnych wydarzeń składających się na barwną historię Izraela związaną z osiedlaniem się w Kanaanie oraz niosły ze sobą konkretne przesłanie dla ówczesnych ludzi i przyszłych pokoleń.

Bardzo ważny motyw kamienia - związany z odnowieniem przymierza w Sychem - występuje jeszcze w Joz 24.

\section{Czas powstania Joz 24}

Księga Jozuego, podobnie jak Pięcioksiąg, jest wynikiem długiego procesu powstawania i opiera się na różnych źródłach. Niektóre z nich są bardzo stare, ale można też odnaleźć wzmianki dotyczące czasów późniejszych niż okres Jozuego (np. o Judzie i Izraelu, a przecież podział ten miał miejsce dopiero po śmierci króla Salomona). Zatem ostateczna redakcja księgi nastąpiła stosunkowo późno. Poszczególne fragmenty, przekazywane i wzbogacane przez tradycję, stały się podstawą redakcji w ramach tzw. nurtu deuteronomistycznego ${ }^{21}$. Redakcja Joz $-2 \mathrm{Krl}$ miała miejsce w trudnym dla Izraelitów czasie, który był związany z niewolą babilońską, zburzeniem Jerozolimy oraz świątyni (VI w. przed Chr.). Mimo iż Księga Jozuego inauguruje opus deuteronomicum, to jednak - w świetle współczesnych badań - należy ona do najmłodszych opracowań historyczno-profetyczno-nomistycznych, po księgach 1-2 Krl, 1-2 Sm i Sdz ${ }^{22}$.

Gdy chodzi teraz o czas powstania Joz 24, to opinie egzegetów są w tym względzie podzielone. Zebrał je

21 Jelonek, Księgi historyczne, 32.

22 Łach, Księga Jozuego, 57-58. 
i szczegółowo zestawił S. Wypych ${ }^{23}$. Według niektórych uczonych (np. J. Wellhausen, E. Hollenberg, A. Dillmann, H. Gressmann, O. Eissfeldt) Joz 24,1-33 pochodzi ze źródła E. Inni egzegeci (np. J.E. Smend) dopatrywali się tu fragmentów źródła J (Joz 24,5-7.9-11.17.25-27). L. Perlitt nie wykluczał, że tekst ten mógł powstać za rządów króla Manassesa i został jedynie opracowany przez deuteronomistę. E. Blum oraz E.W. Nicholson datowali powstanie Joz 24 na okres uprowadzenia. Jeszcze inni uczeni (np. J.L'Hour, A.D.H. Mayers) twierdzili, że fragment ten mógł zostać spisany po niewoli babilońskiej. Tak też sądził J. van Seters, który zaznaczył, iż autorem tego tekstu nie jest deuteronomista, ale jahwista. Natomiast S.D. Sperling był zdania, że rozdział ten mógł powstać na północy, za panowania Jeroboama II.

S. Wypych przedstawił kolejno w swoim opracowaniu różne hipotezy biblistów na temat Joz 24. I tak np. M. Noth oraz G.E. Wright dostrzegali w tym fragmencie przeddeuteronomistyczną tradycję, która jednak została włączona do dzieła dość późno (najprawdopodobniej jako dodatek). J. Agius zaznaczył, że Joz 24,2b-13 pochodzi od deuteronomisty, który skorzystał jednak z wcześniejszych materiałów. J. Delorme i J. Briend stwierdzili, że ostatni rozdział Księgi Jozuego został dość mocno przepracowany pod wpływem teologii deuteronomistów. J.L'Hour był zdania, że rozdział ten zamyka pewien okres dziejów, a w. 31 wydaje się już wprowadzeniem do Księgi Sędziów. Perlitt, Hoffmann i Gibling bronili jednak zwartości tego tekstu. Natomiast Floss i Molle uważali, iż w tym fragmencie można doliczyć się sześciu lub nawet siedmiu warstw redakcyjnych. Wreszcie P. D. Baldi i C. Brekelmans również podkreślali jedność ostatniej części Księgi Jozuego z poprzedzającymi rozdziałami, choć ten ostatni uczony przyznał jednocześnie, iż Joz 24 różni się od pozostałej części księgi, dlatego też nie dziwi się, że wielu egzegetów traktuje go jako niezależną jednostkę.

${ }^{23}$ Wypych, Przymierze i jego odnowa, 81-95; zob. też: Szamocki, „Język integracji narodowej”, 16-19. 


\section{Struktura literacka Joz 24}

Trzy ostatnie rozdziały Księgi Jozuego (Joz 22-24) stanowią duchowy testament tego przywódcy ${ }^{24}$. Fragment ten pełni funkcję zakończenia - jak niegdyś Izrael był zjednoczony w walce o Ziemię Obiecaną, tak w Sychem zgromadził się wokół Jozuego i oddał cześć Jahwe ${ }^{25}$. Wraz z Joz 1 omawiany passus tworzy teologiczne ramy całej księgi, bowiem w rozdz. 1 Pan wezwał Jozuego do wierności, a z kolei w rozdz. 24 do takiej samej postawy wezwali Izraelitów Jahwe i Jozue ${ }^{26}$. Temat wierności jest jakby nicią łączącą poszczególne fragmenty Księgi Jozuego. Postawa ta wynikała z przymierza zawartego między Bogiem a Izraelem na Synaju. We wcześniejszych księgach tą szlachetną drogą wierności kroczyli: Mojżesz, Jozue, Kaleb oraz nieliczni przedstawiciele narodu wybranego. Zupełnie przeciwną sytuację można znaleźć w Księdze Jozuego. Izraelici, wpatrzeni we wzorową postawę swego przywódcy oraz pamiętając o tragicznych losach swych przodków, którzy nie odznaczali się wiernością względem Jahwe, zaczęli iść drogą posłuszeństwa Bogu, gdyż tylko taka postawa gwarantowała spełnienie się Bożych obietnic $^{27}$.

Gdy chodzi już konkretnie o strukturę Joz 24, to można w tym fragmencie wyróżnić następujące części: wstęp $\mathrm{z}$ podaniem miejsca i adresatów wypowiedzi Jozuego (w. 1); mowa Jozuego, w której zostały przypomniane liczne Boskie interwencje względem Izraelitów oraz ich przodków (w. 2-13); dialog Jozuego z ludem, podczas którego przywódca zachęcał Izraelitów do wierności Jahwe i uzyskał pozytywną odpowiedź (w. 14-24); zawarcie przymierza i wezwanie świadków (w. 25-27) oraz rozesłanie ludu (w. 28). Księgę Jozuego zamyka zwięzła informa-

${ }^{24}$ Jelonek, Księgi historyczne, 33.

${ }^{25}$ Coogan, „Księga Jozuego”, 210.

${ }^{26}$ Sanchez Cetina, „Księga Jozuego”, 450.

${ }^{27}$ Dziadosz, „Boża i ludzka wierność”, 55-56. 
cja dotycząca trzech grobów: Jozuego, Józefa i Eleazara (w. 29-33).

S. Wypych podzielił ostatni rozdział Księgi Jozuego następująco: wprowadzenie (w. 1-2a); zwięzłe przypomnienie historii (w. 2b-13); bezpośrednie zwrócenie się Jozuego do słuchaczy z wezwaniem, aby dokonali słusznego wyboru (w. 14-15); odpowiedź ludu (w. 16-18); dialog Jozuego z ludem (w. 19-24); zawarcie przymierza (w. 25-26) oraz wezwanie świadków i rozesłanie ludu (w. 27-28) ${ }^{28}$.

Natomiast M.H. Woudstra zaproponował taki podział rozdz. 24: zgromadzenie wezwane do Sychem (w. 1); profetyczne wejrzenie na historię zbawienia (w. 2-13); napomnienie i reakcja (odpowiedź) (w. 14-24) oraz dokumentacja przymierza (w. 25-28) ${ }^{29}$.

\section{WYJĄTKOWY ŚWIADEK ZGROMADZENIA W SyChem (Joz 24,1-28)}

Wszystkie pokolenia Izraela, starsi, książęta, sędziowie i zwierzchnicy zgromadzili się w Sychem ${ }^{30}$ pod przewod-

${ }^{28}$ Wypych, Przymierze i jego odnowa, 94.

${ }^{29}$ Zob. Woudstra, The Book of Joshua, 340-362.

${ }^{30}$ Sychem to miejsce położone w paśmie górskim po zachodniej stronie Jordanu, w połowie drogi między Nazaretem i Jerozolimą. W późniejszych czasach teren ten określano mianem gór Efraima (od imienia drugiego syna Józefa), zob. Bartoszewicz, „Ośrodki kultu starotestamentalnego", 117. Można przypuszczać, że Sychem - jeszcze przed epoką patriarchów - było kananejskim sanktuarium, zob. Bogacz, „Sanktuaria Izraela w epoce patriarchów”, 138. W miejscu tym stał dąb More, pod którym obwieszczano pogańskie wyrocznie. Nazywany był także terebintem nauczyciela lub wróżbity, zob. Castelot - Cody, „Instytucje religijne Izraela”, 1953-1954. Sychem związane było z osobą Abrahama (Rdz 12,6-7 - tradycja jahwistyczna). Bóg ukazał się patriarsze i zapowiedział oddanie tych ziem jego potomkom. Po tym wydarzeniu Abraham zbudował ołtarz dla Pana. Zatem można powiedzieć, że Sychem było najstarszym ośrodkiem kultu Izraela w Kanaanie. Miejsce to obecne było również w historii Jakuba (Rdz 33,18-20 - tradycja elohistyczna). Patriarcha ten nabył od synów Chamora teren, na którym rozbił swe namioty i ustawił ołtarz. W Sychem miało miejsce odnowie- 
nictwem Jozuego. Zapewne zamiarem autora natchnionego było podkreślenie w ten sposób jedności całego narodu. Element religijny był bowiem najskuteczniejszym czynnikiem integrującym różne pokolenia ${ }^{31}$. Niektórzy uczeni (np. G. von Rad) twierdzą, iż owe zgromadzenie w Sychem mogło się odbyć w związku ze świętem lub religijną uroczystością, podczas której składano ofiary i czytano Prawo. Być może na taką uroczystość przyniesiono nawet z Szilo Namiot i Arkę Przymierza ${ }^{32}$. Jednak z drugiej strony słowa: „stawili się przed Bogiem” można też rozpatrywać w znaczeniu moralnym, duchowym.

Mowa Jozuego rozpoczęła się od słów: „Tak mówi Pan, Bóg Izraela". Powoływanie się na Jahwe i Jego autorytet było charakterystyczne dla proroków i wzmacniało rangę wypowiedzi (np. $1 \mathrm{Krl} \mathrm{17,14;} 2 \mathrm{Krl}$ 19,20; Jr 11,3). Jozue był nie tylko charyzmatycznym przywódcą, ale też wiernym sługą Boga, który to wielokrotnie dodawał Jozuemu odwagi i zapewniał o swojej bliskości (np. Joz $1,5.9 .17 ; 3,7)$. Na szczególną uwagę zasługuje też zastosowanie 1. os. 1. poj. w odniesieniu do Jahwe ${ }^{33}$.

Wypowiedź zawarta w Joz 24,2-1334 stanowiła swoistą lekcję historii dla narodu wybranego, z której Izraelici

nie przymierza, które niegdyś Jahwe zawarł z narodem wybranym na Synaju (Joz 24,1-28), tu też pochowano kości Józefa zabrane z Egiptu (Joz 24,32). Od czasu Jozuego Sychem stało się centrum kraju (Sdz 9,37), punktem dośrodkowym dwunastu pokoleń Izraela oraz „niekoronowaną królową kraju”, zob. Poniży, „Pierwsze sanktuaria Izraela”, 11.

${ }^{31}$ Fanuli, Duchowość Starego Testamentu, 168.

32 Łach, Księga Jozuego, 375.

${ }^{33}$ Fragment mowy Jozuego (Joz 24,2-13) świadczy o tym, że był on przedstawicielem i ambasadorem Jahwe w dosłownym tego słowa znaczeniu, zob. Boling - Wright, Joshua, 534. Jozue przekazał orędzie samego Boga. Jego treścią była historia Izraela, której Jahwe był głównym bohaterem i protagonistą. Występujące tu 18 form czasownikowych w pierwszej osobie odnoszą się do czynności, których podmiotem był Bóg. To On opowiedział historię Izraela, mówiąc jednocześnie o tym, co zdziałał dla tego ludu, zob. Szamocki, „Język integracji narodowej”, 20.

34 Joz 24,2-13 jest przypomnieniem wielkich dzieł Boga w historii zbawienia. Mowa Jozuego dotyczyła wydarzeń: po drugiej stronie rzeki (Joz 2b-4), w Egipcie i na pustyni (Joz 24,5-7), w Zajordanii 
mieli wyciągnąć wnioski na przyszłość. Bóg - ustami Jozuego - przypomniał swemu ludowi ich dawnych przodków (m.in. Teracha), którzy „mieszkali po drugiej stronie Rzeki [Eufratu] i służyli bogom cudzym”. Być może autor natchniony chciał w ten sposób nawiązać do sytuacji niewoli babilońskiej, podczas której niektórzy adresaci jego dzieła odwrócili się od Jahwe i zaufali bożkom pogańskim $^{35}$.

W dalszej części Bóg - ustami Jozuego - przywołał postać Abrahama, który został powołany, wyprowadzony ze swej rodzinnej ziemi, sprowadzony do Kanaanu i obdarzony potomkiem - Izaakiem. Wspomniani zostali także synowie Izaaka - Jakub i Ezaw oraz przeniesienie się tego pierwszego do Egiptu. W omawianym fragmencie nie ma jednak żadnej wzmianki na temat Józefa.

Bóg - ustami Jozuego - wymieniał kolejno Mojżesza i Aarona, którzy na Jego polecenie i z Jego pomocą wyprowadzili naród wybrany z niewoli egipskiej. Pominięty jednak został motyw ciężkiej pracy Izraelitów, natomiast spośród plag pośrednio została wspomniana tylko ostatnia, po której naród wybrany mógł opuścić Egipt. Omawiany tekst przywołuje kolejno: wyjście z niewoli egipskiej, pogoń wojsk faraona za Izraelitami, modlitwę błagalną narodu wybranego, wyratowanie Izraelitów z rąk Egipcjan nad Morzem Sitowia [Czerwonym] oraz długi pobyt na pustyni - jednak bez jakiejkolwiek wzmianki o przymierzu między Bogiem a Izraelem na Synaju. Warto zaznaczyć, iż w początkowym fragmencie w. 7 spotyka się chwilowe

(Joz 24,8-10) oraz w Cisjordanii (Joz 24,11-13), zob. Wypych, Przymierze i jego odnowa, 114. Słowa Jozuego przypominają wypowiedź Samuela (1 Sm 12). Pomiędzy tymi dwoma tekstami zachodzi jednak różnica w kompozycji. Samuel odwołał się do posługiwania Mojżesza i Aarona. Jozue cofnął się do: powołania Abrahama, czasów patriarchalnych, mówił o przeniesieniu się do Egiptu i o cudownym wyjściu z niego, o przebywaniu na pustyni i o zwycięstwach odniesionych na wschód od Jordanu. Jozue zakończył swoją wypowiedź wzmianką o cudownym przejściu Jordanu i o zwycięstwach w ziemi Kanaan, zob. Kruszyński, Pismo Święte Starego Testamentu, II, 130-131.

${ }^{35}$ Łach, Księga Jozuego, 376-377. 
przejście od 1. do 3. os. 1. poj. w odniesieniu do Jahwe. Świadczy to zatem o złożonej historii redakcji tekstu.

W dalszej części przywołane zostały zwycięstwa odniesione nad Amorytami i zajęcie ich ziem. Zapewne chodziło o pokonanie dwóch królów amoryckich - Sichona i Oga (zob. Lb 21,21-35; 32,33; Pwt 1,5; 2,24-25.; 4,46$47 ; 29,6-7 ; 31,4$; Joz 2,10; 9,10; 12,1-6; 13,8-12). W omawianym fragmencie mocno doszedł do głosu motyw Bożej interwencji na korzyść Izraela, a przeciw nieprzyjaciołom narodu wybranego ${ }^{36}$. Wspomniana została również walka z królem Moabu Balakiem oraz historia z Balaamem, którego Balak poprosił, by przeklął Izraelitów ${ }^{37}$. Naród wy-

${ }^{36}$ Termin „święta wojna” nie występuje w Piśmie Świętym. W Księdze Joela spotyka się natomiast zwrot „uświęcić wojnę" (Jl 4,9). W dalszej części tego tekstu można przeczytać o tym, że Bóg będzie sądził narody w Dolinie Jozafata, z kolei na Syjonie będzie On dla swego ludu ucieczką i ostoją (Jl 4,16). Izrael był przekonany, że nie trzeba iść na wojnę, gdyż Pan uratuje swój naród w inny sposób. Zwrot „uświęcić wojnę" znajduje się w bliskości takich motywów, jak: mobilizacja, tworzenie oddziałów czy produkcja broni, ponieważ w całym starożytnym świecie było nie do pomyślenia, by wojny lub inne działania państwowe pozbawione były czynności ofiarnych, odwoływania się do wyroczni czy też innych rytów. Zatem wszystkie działania wojenne poprzedzone były różnego rodzaju rytuałami religijnymi, zob. Lohfink, „«Święta wojna » i «klątwa» w Biblii”, 10-12. Z drugiej strony w wielu miejscach Pisma Świętego można przeczytać o tym, że to sam Jahwe walczył po stronie Izraelitów i oddał w ich ręce poszczególnych nieprzyjaciół, a nawet, że to sam Bóg walczył zamiast swego ludu (np. Joz 6,2; $8,1 ; 10,8.11 .14 .42 ; 13,6 ; 23,3.10)$. Na ten motyw zwrócił również uwagę Jozue podczas przemówienia w Sychem (np. Joz 24,5-8.11-12). W tym przypadku nie bez znaczenia jest etymologia jego imienia. Pełna forma hebrajska tego imienia to Jehoszua (czasem bywa skracana do Jeszua), co oznacza „Jahwe zbawia”. Imię to było symbolicznym wyznaniem wiary w Boga - jedynego wybawcy swego ludu - i w Jego moc, zob. Tronina, „Jozue”, 42; Jasinski, „Motyw zwycięskiej modlitwy”, 32.

${ }^{37}$ Ludy starożytne były przekonane o mocy wypowiadanego słowa (błogosławieństwa lub przekleństwa). Bano się słów przekleństwa, które mocniej poruszały ludzkie sumienia niż ustawy prawne. Znane były przypadki przeklinania wrogów. Ich celem była chęć zaszkodzenia nieprzyjaciołom oraz sprowadzenia na nich nieszczęścia. Przekleństwo służyło też do tego, by uchronić: dokumenty przed ich fałszowaniem, 
brany pokonał bowiem Amorytów i król Moabu zaczął się ich obawiać. Balaam - dzięki interwencji Jahwe - zamiast przekląć Izraelitów, aż trzykrotnie wypowiedział w ich stronę słowa błogosławieństwa.

W w. 11 znalazła się lakoniczna wzmianka o przejściu przez Jordan oraz wspomnienie walki z mieszkańcami Jerycha. Co ciekawe, w Joz 6 o takich działaniach zbrojnych nie ma żadnej bezpośredniej relacji. Następnie wymienione zostały ludy, które Jahwe wydał w ręce Izraelitów: Amoryci, Peryzzyci, Kananejczycy, Chetyci, Girgaszyci, Chiwwici oraz Jebusyci. W tradycji Kpł liczba siedem miała znaczenie teologiczno-kerygmatyczne oraz religijno-kultyczne, a nie tylko schematyczne. Wzmiankę o siedmiu narodach tłumaczono w ten sposób, że Izraelici musieli walczyć ze wszystkimi obcymi ludami - zamieszkującymi Ziemię Obiecaną - i wszystkich ich pokonali dzięki zbawczej interwencji Jahwe ${ }^{38}$.

W kolejnej części mowy raz jeszcze przywołani zostali królowie amoryccy (zob. Joz 24,8). Zostali oni zwyciężeni przez Jahwe, który skierował przeciwko nim szerszenie (zob. Wj 23,28; Pwt 7,20 i Mdr 12,8). Owady te mogły symbolizować trwogę Kananejczyków lub potęgę Egipcjan. Z drugiej jednak strony mogło rzeczywiście chodzić o prawdziwe szerszenie ${ }^{39}$. Wzmiankowanie tak licznych i nadzwyczajnych interwencji Boga względem narodu wybranego miało im uzmysłowić, że wszelkie zwycięstwa nad nieprzyjaciółmi nie zostały osiągnięte za pomocą miecza czy łuku (zob. Ps 44,2-9), ale że stał za nimi sam Pan, oraz to, że Ziemia Obiecana, jej miasta,

przywileje przed ich lekceważeniem, święte budowle i groby przed ich profanacją oraz jako sankcja różnego rodzaju umów. Wierzono, że Bóg wyjątkowo szybko reaguje na przekleństwa ciemiężonych, wdów, sierot, dzieci i ślepych. Przekleństwo stało się zatem bronią wszystkich uciśnionych przeciwko ich wrogom, zob. więcej w: Filipiak, „Społeczno-prawne znaczenie złorzeczeń", 32-39.

${ }^{38}$ Łach, Księga Jozuego, 379.

${ }^{39}$ Gacek, Księga Jozuego, 360. 
winnice i drzewa oliwne zostały im dane za darmo (zob. Pwt 6,10-11) ${ }^{40}$.

Wers 13. zakończył mowę Jozuego dotyczącą przeszłości i rozpoczął nową sekcję, na którą składać się będą pouczenia. Jak w pierwszej części Bóg przemawiał przez usta Jozuego (charakterystyczna 1. os. 1. poj. w odniesieniu do Jahwe), tak w drugiej Jozue wypowiada się już samodzielnie i mocą swojego autorytetu. Wezwał on naród wybrany, by służył Jahwe w szczerości i prawdzie

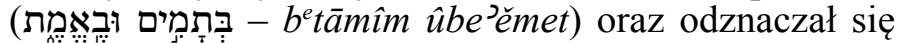
Bożą bojaźnią. Miała to być służba doskonała, wierna i wyłączna, z czym wiązało się wypełnianie wszystkich przepisów Prawa. Chodziło zwłaszcza o odrzucenie bóstw, którym służyli ich przodkowie (może autor natchniony miał także na myśli przejawy bałwochwalstwa Izraelitów w niewoli babilońskiej $)^{41}$. Postawa członków narodu wy-

${ }^{40}$ Warto w tym miejscu zacytować Józefa Flawiusza: „Gdy Jozue był już bardzo stary, przywołał do siebie najznakomitszych mężów z miast oraz naczelników i starszych [...]; gdy się zebrali, przypomniał im o wszystkich dobrodziejstwach Bożych - a wielu z nich doznał lud, który z lichego bytu wydźwignął się do tak wspaniałej chwały i zamożności [...]", zob. Dąbrowski, Dawne dzieje Izraela, 271. To wydźwignięcie Izraela z lichego bytu, wszelka pomyślność w dziejach narodu wybranego oraz cała jego tożsamość nie były wynikiem ludzkiego działania oraz siły, lecz rezultatem Boskiego wyboru i licznych interwencji Jahwe, zob. Butler, Joshua, 272.

${ }^{41}$ Łach, Księga Jozuego, 380. Józef Flawiusz zanotował: „Jozue powiedział im [Izraelitom], by nigdy nie zrazić do siebie Boga, winni trwać w pobożności, bo tylko ona zdoła zachować dla nich Jego przychylność", zob. Dąbrowski, Dawne dzieje Izraela, 271. Ta pobożność Izraelitów była wielokrotnie wystawiana na próbę w związku z: kultem praktykowanym przez przodków i wyniesionym z Mezopotamii; kultem zwierząt, do którego Izraelici przywykli w Egipcie, oraz kultem, z którym naród wybrany zetknął się wśród pogańskich ludów Kanaanu, zob. Kruszyński, Pismo Święte Starego Testamentu, 133. Odwołanie się Jozuego do wierzeń Amorytów miało uzmysłowić Izraelitom, że fałszywy i bałwochwalczy kult nie był cechą tylko odległych przodków mieszkających ,po drugiej stronie Rzeki” [Eufratu] czy też bezpośrednich przodków przebywających w Egipcie, ale że tak naprawdę on się jeszcze nie zakończył - nawet po wejściu do Kanaanu. Nie powinny 
branego miała być daleka od hipokryzji. Chodziło o to, by wewnętrzne przekonania miały odzwierciedlenie w zewnętrznym zachowaniu ${ }^{42}$. Służba Izraelitów nie miała się cechować dwulicowością, polegającą na oficjalnym kulcie Jahwe i potajemnej czci oddawanej domowym bożkom ${ }^{43}$.

Izraelici - na polecenie Jozuego - mieli dokonać wyboru, czy chcą służyć bóstwom, którym cześć oddawali ich przodkowie, czy bóstwom Amorytów, w kraju których zamieszkali, czy też Jahwe. Jozue - jako pierwszy - publicznie wyznał swoją wiarę w Jahwe i zadeklarował: „Ja sam i mój dom służyć chcemy Panu" (Joz 24,15). W chwili wielkiego przeżycia religijnego Jozue wyrzekł zatem mocne słowa z przysięgą ${ }^{44}$. Na szczególną uwagę zasługuje również użycie w omawianym fragmencie wielu czasowników w trybie rozkazującym. Jozuemu bardzo zależało na tym, by Izraelici dokonali właściwego wyboru, gdyż tylko opowiedzenie się po stronie Jahwe gwarantowało wypełnienie się Bożych obietnic.

Wersy 16-18 stanowią odpowiedź Izraelitów, którzy publicznie wyrzekli się bałwochwalstwa. Wyznali oni wiarę w Jahwe - Pana wyjścia i podboju ${ }^{45}$ - oraz zadeklarowali, że tylko Jemu będą służyć. Izraelici dostrzegali Bożą obecność tak w świecie naturalnym, jak i w historii narodu. Czymś obcym było dla nich dzielenie zjawisk na naturalne oraz nadnaturalne. W ich myśleniu nawet naturalny bieg rzeczy był znakiem obecności Pana. W odpowiedzi Izraelitów na wezwanie Jozuego do wierności Jahwe pojawia się sformułowanie: הוּא אֵלהָינוּ (hîu ’élōhênû) - „On jest naszym Bogiem" (w. 18). Występuje ono często w tradycji deuteronomistycznej i stanowi przypomnienie formuły przymierza: „Ja jestem waszym Bogiem, wy jesteście moim ludem"46. To credo z Sychem stanowiło podstawę

zatem dziwić ostre słowa Jozuego, który wezwał Izraelitów do wiernej służby Jahwe - Jedynemu Bogu, zob. Howard, Joshua, 434.

${ }^{42}$ Woudstra, The Book of Joshua, 351.

${ }^{43}$ Cylkow, Księga Jozuego, 160-161.

${ }^{44}$ Strąkowski, ,Jozue", 20.

${ }^{45}$ Sanchez Cetina, „Księga Jozuego”, 452.

${ }^{46}$ Wypych, Przymierze i jego odnowa, 268. 
jedności wszystkich plemion. Izraelici uznali bowiem Jahwe za swego narodowego Boga ${ }^{47}$.

W w. 19 znów wypowiada się Jozue, który przypomniał narodowi wybranemu, że Jahwe jest Bogiem

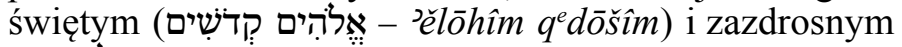

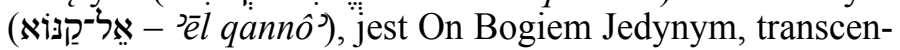
dentnym, przewyższającym wszystko, co istnieje, doskonałym oraz wielce miłującym swój lud. Tylko Jemu należy się wyłączna cześć, ale nie według własnego (ludzkiego) uznania, tylko poprzez zachowywanie Jego wskazań ${ }^{48}$. Ta wierna oraz wzorowa służba narodu wybranego względem Jahwe miała zapewnić Jego przychylność i błogosławieństwo oraz odwrotnie - grzechy oraz występki Izraelitów (szczególnie bałwochwalstwo) miały spowodować odwrócenie się Boga od swego ludu, a to z kolei wiązałoby się z nadejściem nieszczęść i zagłady.

Po słowach Jozuego ponownie zabrali głos Izraelici, którzy - po raz drugi - opowiedzieli się po stronie Jahwe.

${ }^{47}$ Lach, Ksiega Jozuego, 382. Pozytywna odpowiedź Izraelitów na wezwanie Jozuego do wiernej służby Jahwe - Bogu Jedynemu wiązała się z zaangażowaniem ich woli i emocji. Stwierdzili bowiem, że Pan zawsze był i będzie obiektem ich kultu, zob. Madvig, „Joshua”, III, 368-369.

${ }^{48}$ Łach, Księga Jozuego, 382. Jahwe jest święty i nie toleruje żadnych rywali. Przymiotnik, ,święty" można rozpatrywać na dwóch płaszczyznach $-\mathrm{z}$ jednej strony, Bóg oddzielony jest od grzesznej ludzkości, a $z$ drugiej strony, żadne inne bóstwo nie jest jak Pan, nie może się ani porównywać, ani równać z Jahwe, który jest całkowicie różny od innych bogów. Przymiotnik ,zazdrosny” z kolei wyraża roszczenia Jahwe odnośnie do swego ludu, od którego wymaga On bezwzględnego posłuszeństwa, zob. Bratcher - Newman, A Translator's Handbook on the Book of Joshua, 310. Zazdrość pojawia się wówczas, gdy wzajemna miłość oblubieńca i oblubienicy jest zagrożona przez osobę z zewnątrz (zob. Prz 6,32-35; Lb 5,12-31). W takim przypadku zazdrość współmałżonka jest reakcją naturalną. Chodzi bowiem o obronę miłości małżeńskiej. Boża zazdrość chroni więź miłości pomiędzy Jahwe a Jego ludem. Bóg nie pozwala, by Izraelici kalali swoją świętość poprzez czczenie obcych bóstw, które w rzeczywistości są nicością. Zazdrość Jahwe broni zatem podstaw egzystencji Izraela jako narodu wybranego, zob. Pietkiewicz, „Obraz Boga”, 136-137. 
Tym razem uczynili to w sposób zwięzły i stanowczy. Tego dnia lud zawarł umowę z Bogiem. Pierwowzorem takiego przymierza były bliskowschodnie traktaty, w czasie zawierania których powoływano na świadków bóstwa suzerena oraz wasala. W omawianym fragmencie rolę świadków wzięli na siebie sami Izraelici (w. 22). Jozue raz jeszcze wezwał ich, by odrzucili bałwochwalstwo i zwrócili swe serca $^{49}$ ku Jahwe. Chodziło o radykalne i całościowe (całym ich jestestwem) opowiedzenie się narodu wybranego po stronie Pana. Omawiany dialog zakończyła wypowiedź Izraelitów, którzy już po raz kolejny zapewnili Jozuego - pośrednika przymierza między Bogiem a narodem wybranym - że chcą służyć Jahwe i słuchać wyłącznie Jego głosu.

W ten sposób zaistniał szczególnie bliski związek Izraela z Jahwe (przymierze), który określany jest hebrajskim

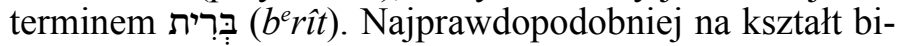
blijnych przymierzy duży wpływ miały hetyckie traktaty z II tys. przed Chr., które składały się z następujących elementów: wstęp, historyczny prolog, wykaz praw i obowiązków, nakaz złożenia ofiary w świątyni i odczytywania tego dokumentu w określonym czasie, lista bóstw powoływanych na świadków oraz formuła błogosławieństw i przekleństw ${ }^{50}$.

W omawianym fragmencie (Joz 24,1-28) można natknąć się na niektóre $\mathrm{z}$ tych elementów. Przymierze zawarte zostało pomiędzy Bogiem a ludem (עַם - C am). Po-

${ }^{49} \mathrm{Z}$ jednej strony terminem tym określa się wewnętrzny narząd człowieka, który wiąże się z mocą, siłą witalną oraz życiem fizycznym, a z drugiej strony - używając tego terminu w znaczeniu metaforycznym - mamy na myśli centrum życia duchowego oraz siedlisko myśli, uczuć i woli. Zatem ludzkie serce: myśli, rozważa i decyduje. Oznacza ono także najgłębsze wnętrze człowieka, ludzkie ,ja”, sumienie. Jakość serca ma ogromny wpływ na ludzkie działanie. To właśnie w sercu dokonuje się decyzja: ,jestem z Bogiem” lub ,jestem przeciw Bogu”. Nic więc dziwnego, że serce może być: dobre lub złe, twarde lub miękkie (wrażliwe), niewierne lub wierne, zamknięte lub otwarte, obrzezane lub nieobrzezane itd., zob. Mazanka, ,Refleksje”, 74-75.

${ }^{50}$ Zob. Mendenhall, Law and Covenant, 41-44. 
średnikiem tego paktu był Jozue. Zgodnie z testamentem Jozuego oraz z innymi materiałami deuteronomistycznymi każdy ojciec rodziny był odpowiedzialny za to, by jego potomstwo znało przymierze i jego warunki. Takie wychowanie miało $\mathrm{z}$ kolei promieniować $\mathrm{z}$ domu rodzinnego na cały naród ${ }^{51}$. Po historycznym wstępie (Joz 24,2-13) strony określiły swoje zobowiązania. Izraelici obiecali odwrócić się od bałwochwalczego kultu. Mieli być natomiast wierni Jahwe, służyć Mu w szczerości oraz prawdzie, przylgnąć do Niego całym swym sercem (jestestwem), słuchać Jego głosu i odznaczać się Bożą bojaźnią. Takie postępowanie miało zapewnić im błogosławieństwo ze strony Jahwe. Gdyby jednak Izraelici złamali przymierze i odeszli od swych zobowiązań, miały czekać ich nieszczęścia, a nawet zagłada. Jozue zapisał wszystkie te słowa w księdze Prawa Bożego, która miała stale towarzyszyć ludowi ${ }^{52}$, a na świadków zawartego traktatu powołani zostali sami Izraelici (nie jakieś bóstwa, gdyż Jahwe jest Bogiem Jedynym). W analizowanym tekście nie pojawia się wyraźna formuła błogosławieństw i przekleństw oraz motyw złożenia ofiary, przecięcia zwierząt i przejścia obu kontrahentów pomiędzy nimi (np. Rdz 15,9-21).

$\mathrm{Na}$ zakończenie spotkania w Sychem, zanim lud został odprawiony i powrócił do swoich posiadłości, Jozue wziął wielki kamień i umieścił go pod terebintem. Było to długowieczne i rozłożyste drzewo, które zazwyczaj rosło pojedynczo w niższych partiach gór w Palestynie i na pustyni Negeb. Drzewa te chroniły przed promieniami słonecznymi oraz były doskonałym miejscem zgromadzeń o charakterze kultycznym ${ }^{53}$. Z tym terebintem związana była historia Abrahama oraz Jakuba. Najprawdopodobniej pierwszy z nich zatrzymał się przy nim i zbudował ołtarz ( $\mathrm{Rdz} 12,4-7)$, a drugi zakopał tam posążki obcych bóstw,

51 Sanchez Cetina, „Księga Jozuego”, 453.

52 Najprawdopodobniej to sformułowanie jest określeniem nakazów i zakazów zawartych w Pięcioksięgu, zob. Coogan, „Księga Jozuego”, 212; Römer - Brettler, „,Deuteronomy 34”, 411-412; Łach, Księga Jozuego, 384-385.

${ }^{53}$ Łach, Ksiega Jozuego, 385. 
co wiązało się z odrzuceniem bałwochwalczego kultu (Rdz 35,1-5).

Wielki kamień, który Jozue umieścił pod terebintem w Sychem, miał być świadkiem (hebr. עָדָ - ${ }^{\complement} \bar{e} d \bar{a}^{h}$ ). Ten milczący świadek został podniesiony niemalże do rangi żywego bytu ${ }^{54}$, gdy Jozue oznajmił ludowi, iż ów kamień słyszał wszystkie słowa, jakie Pan wypowiedział w Sychem do Izraelitów. Głaz ten odgrywał zatem rolę tzw. osoby trzeciej, której nie dotyczyło przymierze zawarte między Bogiem a Izraelitami, ale która miała przypominać narodowi wybranemu o złożonych zobowiązaniach względem Jahwe oraz o zawartym przymierzu. Kamień ten miał także świadczyć przeciwko ludowi, aby ten nigdy nie wyparł się swojego Boga. Umiejscowienie pamiątkowego głazu pod terebintem miało także chronić przed jakąkolwiek próbą przyszłego zanegowania zaistniałego wydarzenia w Sychem ${ }^{55}$. Z tego powodu Jozue mógł nawet wypisać na kamieniu warunki zawartego przymierza. Warto także zaznaczyć, iż archeolodzy odkryli w Sychem wielki wapienny kamień, który mógłby być identyfikowany z tym opisanym w Joz $24,26-27^{56}$.

\section{Podsumowanie}

Motyw kamienia często pojawia się na kartach Pisma Świętego. Ta częstotliwość była związana z tym, że kamienie odgrywały bardzo ważną rolę w codziennym życiu mieszkańców Kanaanu. Oprócz praktycznego zastosowania kamienie pełniły także funkcję świadectw. Były one

${ }^{54}$ Animizacja (ożywienie) często spotykana jest na kartach Biblii, np. „Zebrały się drzewa, aby namaścić króla nad sobą. Rzekły do oliwki: «Króluj nad nami!». Odpowiedziała im oliwka: «Czyż mam się wyrzec mojej oliwy, która służy czci bogów i ludzi, aby pójść i kołysać się ponad drzewami?»” (fragment bajki Jotama z Sdz 9,8-15); „Niech rzeki klaszczą w dłonie, niech góry razem wołają radośnie przed obliczem Pana, bo nadchodzi sądzić ziemię" (Ps 98,8-9).

${ }^{55}$ Hubbard, Joshua, 562.

${ }^{56}$ Campbell, ,Joshua”, I, 370. 
bowiem świadkami istotnych wydarzeń w historii narodu wybranego. Do takich kamiennych świadków - wzmiankowanych w Księdze Jozuego - można zaliczyć: dwanaście pamiątkowych kamieni wyciągniętych $\mathrm{z}$ dna Jordanu; gruzy Jerycha; stos kamieni wzniesiony nad zwłokami Akana; gruzy Aj; stos kamieni nad ciałem króla Aj; ołtarz na górze Ebal; odpis Prawa na kamieniach; kamienie zrzucane przez Boga na wojsko królów amoryckich; kamienie zamykające wejście do jaskini, do której wrzucono pięciu królów pokonanych przez Jozuego i jego ludzi; ołtarz plemion zajordańskich oraz duży kamień spod terebintu w Sychem. Ci „kamienni świadkowie” mieli przypominać o wydarzeniach, które rozegrały się w danym miejscu, by uchronić je przed zapomnieniem lub zanegowaniem. Kamienie te niosły również ze sobą konkretne przesłanie dla ówczesnych ludzi i przyszłych pokoleń.

Kamień, który został umieszczony przez Jozuego pod terebintem w Sychem, był świadkiem bardzo ważnego wydarzenia w historii narodu wybranego - zawarcia przymierza z Jahwe. Ten niemy świadek słyszał na samym początku streszczone dzieje Izraela, jakie Bóg wypowiedział przez usta Jozuego. Pan wspomniał: Teracha, który służył obcym bóstwom; Abrahama i jego wyprowadzenie $\mathrm{z}$ rodzinnej ziemi, sprowadzenie do Kanaanu oraz obdarzenie potomkiem - Izaakiem; Jakuba i Ezawa oraz przeniesienie się tego pierwszego do Egiptu; Mojżesza i Aarona, wyjście z niewoli egipskiej, pogoń wojsk faraona za Izraelitami, modlitwę błagalną narodu wybranego, wyratowanie Izraelitów z rąk Egipcjan oraz pobyt na pustyni; zwycięstwa odniesione nad Amorytami i zajęcie ich ziem; walkę z Balakiem oraz historię z Balaamem; przejście przez Jordan oraz zdobycie Jerycha i wreszcie ludy, które wpadły w ręce Izraelitów. Wszystkie te wydarzenia miały uzmysłowić członkom narodu wybranego, że Jahwe jest po ich stronie, że walczy z nimi, a nawet za nich.

Kamień z Sychem był następnie świadkiem przejmującego dialogu pomiędzy Jozuem a Izraelitami. Tego dnia wszyscy zobowiązali się do tego, że: będą służyć Jahwe w sposób doskonały, wierny oraz wyłączny; będą odzna- 
czać się Bożą bojaźnią; będą zwracali swe serca ku Panu; będą przestrzegać przepisów Prawa i odrzucą kult obcych bóstw. Uznanie Jahwe za narodowego Boga oraz przestrzeganie wszystkich tych zobowiązań miało zagwarantować Izraelitom błogosławieństwo i pomyślność. Natomiast grzech miał spowodować odwrócenie się Boga od swego ludu, nieszczęścia, a nawet zagładę.

Ogromny kamień spod terebintu w Sychem był wreszcie świadkiem zawartego przymierza oraz zapisania tych wszystkich ważnych słów w księdze Prawa Bożego. Głaz ten miał przypominać Izraelitom oraz ich potomkom o tym wszystkim, co zostało powiedziane i co dokonało się na tym miejscu. Nade wszystko kamień ten miał przywodzić na myśl wszystkie deklaracje, do których zobowiązali się Izraelici wobec Jahwe oraz motywować naród wybrany do ich przestrzegania. Z tym natomiast - jak pokazuje późniejsza historia narodu wybranego - będzie już trudniej.

\section{Bibliografia}

Achtemeier P.J., „Pamiątki”, Encyklopedia biblijna (red. P.J. Achtemeier) (Warszawa 1999) 894-895.

Bartoszewicz D.K., „Ośrodki kultu starotestamentalnego”, Pan tam jest. Jego Magnificencji Ks. Prof. Ryszardowi Rumiankowi in memoriam (red. Z. Godlewski) (Warszawa 2011) 117-144.

Bogacz R., „Sanktuaria Izraela w epoce patriarchów”, Z badań nad Biblia (red. T. Jelonek) (Kraków 2001) 137-146.

Boling R.G. - Wright G.E., Joshua. A New Translation with

Notes and Commentary (The Anchor Bible 6; New Haven

- London 2008).

Bosak P., „Akan”, Postacie Biblii. Słownik - konkordancja

(P. Bosak) (Poznań 1999) I, 248-250.

Bratcher R.G. - Newman B.M., A Translator's Handbook on the Book of Joshua (London - New York 1983).

Butler T.C., Joshua (WBC 7; Dallas 1998). 
Campbell D.K., „Joshua”, The Bible Knowledge Commentary: An Exposition of the Scriptures (red. J.F. Walvoord - R.B. Zuck) (Wheaton 1985) I, 325-371.

Castelot J.J. - Cody A., „Instytucje religijne Izraela”, Katolicki komentarz biblijny (red. R.E. Brown - J.A. Fitzmyer R.E. Murphy) (Warszawa 2001) 1945-1989.

Coogan M.D., „Księga Jozuego”, Katolicki komentarz biblijny (red. R.E. Brown - J.A. Fitzmyer - R.E. Murphy) (Warszawa 2001) 177-212.

Corbon J., „Pamięć”, Słownik teologii biblijnej (red. X. Léon-Dufour) (Poznań 1994) 639-641.

Cylkow I. (tłum.), Księga Jozuego (Kraków - Budapeszt 2012).

Dąbrowski E. (red.), Dawne dzieje Izraela (Poznań - Warszawa - Lublin 1962).

Deden D., „Stein”, Bibel-Lexikon (red. H. Haag) (Leipzig 1970) 1636-1639.

Dziadosz D., „Boża i ludzka wierność. Teologiczny obraz zdobycia Kanaanu", Verbum Vitae 6 (2007) 43-66.

Edel R., Hebräisch-Deutsche Präparation zu Josua (Marburg 1975).

Fanuli A., Duchowość Starego Testamentu (Kraków 2002).

Filipiak M., „Społeczno-prawne znaczenie złorzeczeń w Piśmie Świętym", Ruch Biblijny i Liturgiczny 21/1-2 (1968) 32-39.

Gacek S., Księga Jozuego (Tarnów 1993).

Howard D.M., Joshua (NAC 5; Nashville 1998).

Hubbard R.L., Joshua (Grand Rapids 2009).

Jamieson R. - Fausset A.R. - Brown D., Commentary Critical and Explanatory on the Whole Bible (Oak Harbor 1997) I. Jasiński M., „Motyw zwycięskiej modlitwy w narracji Joz 10,1-27”, Verbum Vitae 11 (2012) 15-46.

Jelonek T., Księgi historyczne Starego Testamentu (Kraków 2006).

Kruszyński J., Pismo Święte Starego Testamentu. II. Księgi: Jozuego, Sędziów, Ruty, Dwie Samuela i Dwie Królewskie. Przekład z oryginału hebrajskiego. Komentarz (Lublin 1938).

Lamarche P., „Kamień”, Stownik teologii biblijnej (red. X. Léon-Dufour) (Poznań 1994) 360-362. 
Lohfink N., „«Święta wojna » i «klątwa» w Biblii”, Communio 9/5 (1989) 10-19.

Lurker M., „Kamień”, Słownik obrazów i symboli biblijnych (M. Lurker) (Poznań 1989) 82-83.

Lurker M., „Kamień węgielny - kamień fundamentowy”, Słownik obrazów i symboli biblijnych (M. Lurker) (Poznań 1989) 83-84.

Łach J.B., Księga Jozuego. Wstęp - przekład z oryginału - komentarz - ekskursy (Pismo Święte Starego Testamentu III/1; Poznań 2013).

Madvig D.H., „Joshua”, The Expositor's Bible Commentary. III. Deuteronomy, Joshua, Judges, Ruth, 1 \& 2 Samuel (red. F.E. Gaebelein) (Grand Rapids 1992) 239-371.

Mazanka P., ,Refleksje o rozumieniu czystości serca w filozofii i teologii", Fides et Ratio 5/4 (2014) 73-92.

Mendenhall G.E., Law and Covenant in Israel and in the Ancient Near East (Pittsburg 1955).

Michalak A.R., „,Rytuał klątwy w starożytnym Izraelu i ideologia ekspansji”, Przeglad Religioznawczy (2005) 9-23.

Nadolski B., „Eucharystia”, Leksykon liturgii (B. Nadolski) (Poznań 2006) 403-430.

Pietkiewicz R., „Obraz Boga w wypowiedziach bohaterów Ksiąg Historycznych Starego Testamentu", Perspectiva (Legnickie Studia Teologiczno-Historyczne) 9/2 (2010) 136-137.

Poniży B., „Pierwsze sanktuaria Izraela”, Życie religijne w Biblii (red. G. Witaszek) (Lublin 1999) 9-36.

Rabiej S., „Soteriologiczne znaczenie Chrystusowego EGO EIMI', Ateneum Kaplańskie 85/1 (1993) 15-27.

Römer T.C. - Brettler M.Z., „Deuteronomy 34 and the Case for a Persian Hexateuch", Journal of Biblical Literature 119/3 (2000) 401-419.

Ryken L. - Wilhoit J.C. - Longman T., „Kamień”, Słownik symboliki biblijnej (L. Ryken - J.C. Wilhoit - T. Longman) (Warszawa 1998) 294-295.

Ryken L. - Wilhoit J.C. - Longman T., „Kamień węgielny”, Stownik symboliki biblijnej (L. Ryken - J.C. Wilhoit T. Longman) (Warszawa 1998) 295. 
Sanchez Cetina E., „Księga Jozuego”, Międzynarodowy komentarz do Pisma Świętego (red. W.R. Farmer) (Warszawa 2000) 433-453.

Schildenberger J., Literarische Arten der Geschichtsschreibung im Alten Testament (Einsiedeln 1964).

Spence-Jones H., Joshua (London - New York 1909).

Strąkowski H., „Jozue”, Roczniki Teologiczno-Kanoniczne 13/1 (1966) 13-21.

Synowiec J.S., Izrael opowiada swoje dzieje. Wprowadzenie do ksiąg: Powtórzonego Prawa, Jozuego, Sędziów, Samuela i Królewskich (Kraków 1998).

Szamocki G., ,Język integracji narodowej w Joz 24,1-24”, Studia Gdańskie (2012) 15-26.

Świderkówna A., „Od Paschy pierwszego Przymierza do Eucharystii", Wrocławski Przeglad Teologiczny 5/1 (1997) 129-136.

Tronina A., „Jozue - Jezus. Biblijna typologia Zbawiciela”, Verbum Vitae 1 (2002) 41-56.

Woudstra M.H., The Book of Joshua (Grand Rapids 1981).

Wypych S., Przymierze i jego odnowa. Studium z teologii biblijnej Starego Testamentu (Kraków 2003).

Ks. Łukasz Florczyk

ul. I. Radziszewskiego 7

20-039 Lublin

lukasz.florczyk@poczta.onet.pl

Ks. ŁuKasz FlorCzyK, kapłan diecezji opolskiej, magister licencjusz teologii biblijnej (KUL, 2015), doktorant Instytutu Nauk Biblijnych KUL. 